\title{
First Year Challenge: The Role of Self-Regulated Learning to Prevent Internet Addiction among First-Year University Students
}

\author{
Ermida Simanjuntak \\ Faculty of Psychology, Widya Mandala Catholic University \\ Faculty of Psychology, Airlangga University \\ mida@ukwms.ac.id
}

\begin{abstract}
University students are categorized as digital natives group who use internet frequently in their daily life. Several studies mentioned that internet affects the way university students learn and socialize with peers. Referring to the university context, first year of university is a crucial periode where students learn to adjust with academic and social aspects after transforming from highschool period. Thus, first-year students are assumed to be more vulnerable to internet addiction due to academic and social adjustment issues. First-year students will look for support and escape from uncomfortable adjustment situation by accessing the internet. Regarding this situation, self-regulated learning (SRL) is a potential factor than can prevent students from internet addiction. This present study aims to explore the relationship between self-regulated learning (SRL) and internet addiction among first year university students. Participants are first-year students $(\mathrm{N}=76)$, consisting of 14 males and 62 females. Data were collected by using Young's internet addiction test (IAT), self-regulated learning scale (SRLS) adapted from SRSS scale by Kadioglu, Uzuntiryaki \& Aydin (2011) and questionaire. Results showed that significant correlation is found between selfregulated learning and internet addiction $(\mathrm{p}<.05)$. Moreover, there is no significant correlation between GPA and internet addiction as well as SRL also does not correlate with GPA of the participants. SRL indicators of effort regulation and attention-focusing correlate with internet addiction. Further research should consider the improvement of measurement tools to identify internet access behavior and internet addiction among first-year students.
\end{abstract}

Keywords: Self-regulated learning, internet addiction, grade point average, university students.

\section{INTRODUCTION}

The term "Digital Natives" as defined by Prensky in 2001 (cited in Kolikant, 2010; Margaryan, Littlejohn \& Vojt, 2011; Thompson, 2013) refers to the person who was born in or after 1980 with the characteristics of using internet most of the time and possibly doing media multitasking with the internet. Recent university students are categorized as "digital natives" as they were born during the time of the emergence of internet. Several researches in the topic of internet mentioned that university students use internet frequently and as a result, the internet possibly affects the way they learn and socialize with other persons (Margaryan, Littlejohn \& Vojt, 2011; Timmis, 2012; Thompson, 2013; Judd, 2014; Calderwood, Ackerman \& Conklin, 2014; Kononova \& Chiang, 2015; Zhang, 2015). The fond of using internet technology is represented in how university students communicate and learn in their daily life. In the university classrooms, it is common for students to bring laptops to the class as the tools for learning (e.g.taking notes, browsing materials). They also use internet to communicate to other persons such as giving supports to their peers while finishing course project and engaging in social media to connect with family and friends (Timmis, 2012; Alt, 2015). However, some researches also discuss the negative effects of using internet among students such as chatting with friends by using instant messaging during the class, engaging in social media sites while doing assignments and surfing non related learning material during lectures (Junco \& Cotten, 2012; Gaudreau, Miranda \& Gareau, 2014; Calderwood, Ackerman \& Conklin, 2014; Taneja Fiore \& Fischer, 2015; Barry, Murphy \& Drew, 2015).

Despite the positive and negative effects of the internet mentioned by researches, people find that internet has interesting sides: the continuous entertainment, the anonymity in communication, the availability of social connection and the emotional nurturance that can lead person to become dependent on the internet (Young, 1998). Young (2011) also mentioned that internet contains three aspects of addictive behavior : Anonimity, Convenience \& Escape (ACE). Internet can be very entertaining because of the preferable unidentified aspects (anonimity), borderless connection (convenience) and switching to the more comfort activities (escape). Refer to this condition, internet could be potentially addictive to people, particularly students (Kuss, Griffiths \& Binder, 2013). Some research findings show that internet addiction has become a problem for most university students (Iacovelli \& Valenti, 2009; Iskender \& Akin, 2010; Kuss, Griffiths \& Binder, 2013; Taymur, 2016; Niu, et al., 2016). Young (2011) mentioned that adolescents groups including university students has a potential risks to have internet addiction problems. It could be also up to $18.4 \%$ of the population of student internet users in USA are vulnerable to have addiction to the internet (Young, 2011). It is also confirmed by Tsitsika et al. in 2014 
among internet users in Europe that $13,7 \%$ adolescents has potential risks to have internet addiction problems (Taymur, 2016). Moreover, in the Asian context, surveys done in China by Cui, Zhao, Wu \& Xu in 2006 reported that young people who have addiction problems to the internet range up to 10 million users (cited in Young, 2011). Regarding the findings of the previous research, internet addiction in young people especially among university students is considered to be a serious psychological problems.

Internet addiction is defined as the uncontrollable need to constantly access internet that affects users' daily functioning (Young, 2011). Some characteristics that represent in the internet addiction could be extended in four aspects: excessive use with inability to control accessing time; withdrawal or uncomfortable feeling when unable to do internet connection; tolerance, which include the need to use good equipment and software and the time for accessing and negative impact to daily life such as low in academic achievement, less sleeping hours, social isolation and lying (Young, 2011). DSM 5 has been included internet game addiction as one of the mental disorder that need to be given treatments (DSM-5, 2013). However, this internet gaming disorder is more spesific to the internet gamer (DSM-5, 2013). In the area of internet, there are another aspects of internet that can be the source of addiction behaviors such as surfing information in the web, social networking, and even pornography contents. However, for wise internet users, internet can be a media to fulfill those kinds of needs (Widyanto \& Griffiths, 2007).

Related to internet addiction problems among students, some factors have been related to the internet addiction such as personality traits (e.g.neuroticism, agreeableness), low of emotional control, low social self efficacy, lack of social support, academic procrastination and maldaptive behavior (Joinson, 2003; Iskender \& Akin, 2010; Odaci, 2011; Yao, Han, Zeng \& Guo, 2013; Kuss, Griffith, Binder, 2013; Kuss et al., 2013). Furthermore, study by Yao, Han, Zeng, Guo (2013) on first-year students shows that first-year students as a vulnarable group to internet addiction. Most of the researches focus on general university students and there are some lack of researches on internet excessive use on first-year students (Yao, Han, Zeng \& Guo, 2013). First-year students are considered to be the transition period from highchool to the university life that needs some adjustments both in academic and social aspects (Santrock, 2011; Cazan, 2013). Regarding the situation for adjustment, some first-year students might not be able to adjust immediately to the academic life and it can lead to internet addiction (Yao, Han, Zeng \& Guo, 2013). The lack of adjustment will make students to find comfortable activities and internet is seen as an immediate resource for providing the sense of supportive and recreative (Joinson, 2003).

Several studies on first-year students mentioned that self-regulated learning (SRL) plays an important role to affect first-year students' adjusment to the academic life (Hurk, 2006; Santrock, 2011; Cazan, 2013). Self-regulated learning (SRL) is the terminology used by Zimmerman \& Kovach (1996) to describe about the ability of students to regulate their cognition, affection and behaviour to achieve learning goals. Students with high self-regulated learning (SRL) are able to regulate their actions to achieve their learning goals comparing to low SRL students (Zimmerman \& Schunk, 2011). Some research has confirmed that self-regulated learning relates to academic performance (Hurk, 2006; Kitsantas, Winsler \& Huie, 2008; Peng, 2012; Cho \& Cho, 2013; Cazan, 2013; Dorrenbacher \& Perels, 2016). According to Kadioglu, Uzuntiryaki, \& Aydin (2011)). There are several indicators that represent SRL: (1) motivation (2) regulation; (3) planning; (4) effort regulation; (5) attention focusing; (6) task strategies; (7) using additional resources and (8) self instruction.

Previous researches on internet addiction mentioned that self regulation is a potential factor to prevent the uncontrollability of internet use (Dunbar, Proeve \& Roberts, 2017). Students with high self regulation can control themselves for browsing irrelevant information during learning tasks. Some studies also proved that students with better self regulation are able to focus themselves to the learning materials during lectures although they bring laptop to the class (Roca, Williams \& Dowd, 2012; Taneja Fiore \& Fischer, 2015; Zhang, 2015; Wu, 2017). However, the number of research focusing on the relationship between self-regulated learning and internet addiction in the context of first-year students is still low. Most of the researches in the area of internet addiction tend to use samples of students in general and there is still lack of research that explore the internet addiction in the context of first-year students (Yao, Han, Zeng \& Guo, 2013). This current studies aims to explore the relationship between self-regulated learning and internet addiction tendency among first year university students. The present study will also describe the correlation between tendency of internet addiction to the academic performance of the students.

\section{METHOD}

\section{Participants}

Participants in the present study are first-year students in the faculty of psychology at a private university in Surabaya, Indonesia $(\mathrm{N}=86)$. After carefully selected the data, 10 participants are ommitted due to incomplete data and there are 76 participants who were included in the data analysis. There are 14 male students and 62 female students as the participants.

\section{Instruments}

Data were collected using : (1) questionnaires to get information about participants' demographic characteristic (age, gender, GPA); (2) Internet Addiction Test (IAT) developed by Kimberly Young (1998); and (3) Self-regulated learning Scale (SRSS) adapted from SRSS scale by Kadioglu, Uzuntiryaki, \& Aydin (2011).

IAT consits of 20 items in which participants need to respond between $1-5$, ranging from $1=$ not at all; 2 = rarely; $3=$ occasionally; $4=$ often; and $5=$ always. 
There are 3 categorizations for the total score of IAT; 20 - 39 points are considered to be online average user; $40-69$ points means participant has problems toward internet use; and $70-100$ points will categorize participants as severe addicted to the internet.

Self-regulated learning Scale (SRSS) is developed by Kadioglu, Uzuntiryaki, \& Aydin (2011) and has been adapted in Bahasa Indonesia. The scale consists of 28 items with cronbach Alpha 0.88 . There are 8 indicators of SRL in this scale, namely, (1) motivation regulation; (2) planning; (3) effort regulation; (4) attention focusing; (5) task strategies; (6) using additional resources and (7) self instruction.

\section{Procedur}

The questionnaire and scales are distributed to the students after the statistic class by the research assistants. Before delivering the instruments to the participants, the writer gave introduction and procedure of filling in the questionnaire and scales to the participants.

\section{RESULTS}

Descriptive statistics for the variables were selfregulated learning $(\mathrm{M}=99$; $\mathrm{SD}=9.71)$, GPA $(\mathrm{M}=$ $3.15 ; \mathrm{SD}=0.39)$ and internet addiction $(\mathrm{M}=43.39, \mathrm{SD}$ $=12$ ). Pearson correlation in table 1 shows that selfregulated learning and internet addiction were statistically significant among first-year students $(\mathrm{p}<$ $.05)$. Negative correlation between self-regulated learning and internet addiction indicates that low SRL students tend to have high internet addiction. Another finding shows that there is no significant correlation between grade point average (GPA) and internet addiction. Referring to the categorization of internet addiction regarding gender, it can be described that average user among male first-year students is $4 \%$ from the total number of participants and female students average users are $29 \%$. The categorization of moderate user in male students are $14 \%$ and $53 \%$ for female moderate users. However, participants with severe internet problems are not found in this study.

Pearson correlation is also computed for selfregulated learning indicators and internet addiction. Significant correlation was found between effort regulation $(\mathrm{p}<.05)$ and attention focusing $(\mathrm{p}<.01)$. There is no significant correlation between internet addiction and SRL indicators such as motivation regulation, planning, task strategies, additional resources and self instruction.

Table 1. Pearson correlation between self-regulated learning, GPA, and internet addiction

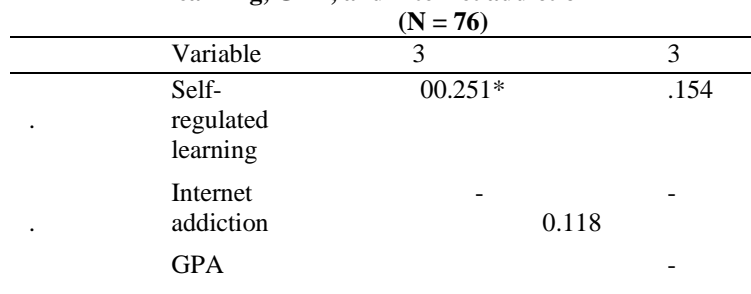

Table 2. Participants' categorization of internet addiction based on gender $(\mathbf{N}=76)$

\begin{tabular}{|c|c|c|c|c|}
\hline \multirow[b]{2}{*}{$\begin{array}{l}\text { Categorizatio } \\
\mathrm{n}\end{array}$} & \multicolumn{3}{|c|}{ Male } & \multirow{2}{*}{$\begin{array}{r}\text { Female } \\
\%\end{array}$} \\
\hline & $\begin{array}{l}\text { Freque } \\
\text { ncy }\end{array}$ & & \% Frequency & \\
\hline Average user & 3 & $\%$ & 22 & $9 \%$ \\
\hline $\begin{array}{l}\text { Moderate } \\
\text { user }\end{array}$ & 11 & $14 \%$ & 40 & $53 \%$ \\
\hline $\begin{array}{l}\text { Severe } \\
\text { problem of } \\
\text { internet user }\end{array}$ & - & & - & - \\
\hline
\end{tabular}

Table 3. Pearson correlation between SRL indicators and internet addiction $(N=76)$

\begin{tabular}{lll}
\multicolumn{1}{c}{ internet addiction $(\mathbf{N}=\mathbf{7 6})$} & $\begin{array}{l}\text { Internet } \\
\text { addiction }\end{array}$ \\
\hline \multicolumn{1}{c}{ Indicators } & .091 & - \\
\hline 1. Motivation regulation & .020 & - \\
2. Planning & $.249 *$ & - \\
3. Effort regulation & $.322 * *$ & - \\
4. Attention focusing & .120 & - \\
5. Using additional resources & .116 & - \\
6. Task strategies & .164 & - \\
7. Self instruction & & \\
& $* p<.05$ \\
$* * p<.01$ &
\end{tabular}

\section{DISCUSSION}

The present research has discovered significant correlation between self-regulated learning and internet addiction among first-year university students. This findings confirm previous research that self regulation is one of the important factor that can prevent students from excessive internet use (Dunbar, Proeve \& Roberts, 2017). First year period in the university is a time for the students to adjust with new academic life and probably this is the period for students to live independently from parents. The availability of internet access in the university and the minimum guidance from parents can lead to the uncontrollable internet use (Walsh, Fielder, Carey \& Carey, 2013). A study by Zhang (2015) about media multitasking among university students mentioned that self regulation behaviour is a strong predictor for doing multitasking in the internet. Students with high self regulation can control their internet use to limit into academic tasks. Moreover students with low self regulation tend to do internet access for unrelated learning materials during the class (Zhang, 2015).

Furthermore, Zimmerman \& Schunk (2011) argued that high SRL students are able to monitor their thoughts, feelings, and behaviors in order to achieve their learning goals. Students with high SRL can regulate their thinking and action regarding excessive internet use that can affect their academic performance. The finding in this study is in line with the concept of self-regulated learning, which argues that students will do some preventive actions to create the environments that support their effort to achieve the goals. The concept of self-regulated learning based on cognitive and behavior perspective is in accordance with concept of CBT to treat person with internet addiction. People 
with internet addiction are taught to monitor their thoughts and control situation that lead them to internet addiction (Young, 2011). This behaviour is similar to the indicators of self-regulated learning in which students will do self-monitoring to evaluate their strategy to achieve learning goals. This present study also shows positive correlation between SRL indicators of effort regulation and attention focusing to internet addiction. Effort regulation is the situation where students can regulate their actions to achieve learning goals. Students with high score in effort regulation can arrange themselves to access the internet to support their study. They will regulate their use of internet to browse information related to their academic tasks, to discuss with friends towards projects or homework and possibly to limit themselves in internet access for unrelevant learning activities during exam preparations.

Regarding the result of GPA and internet addiction that has no significant correlation is found between the two variables. Santrock (2011) mentioned that academic achievement is influenced by external (e.g. teacher, instructional design) and internal factors (e.g. IQ, personality trait, motivation). Internet addiction probably belongs to the internal factors of the individual and is based on the results that there are no severe internet users among participants. Most of the participants falls in the category of moderate internet users that potentially have problems in using the internet. However, Young (2015) asserted that the challenge lies in identifying the appropriate time to go online, since most of the daily activities recently are mostly connected to the internet. The development of the scale in 1998 might need some adjustments regarding the norms, because the pattern in the use of internet nowadays has changed if compared to 1998. It is also difficult to identify whether the participants use the internet for learning or leisure purposes with the concept of media multitasking (Roca, Williams \& Dowd 2012; Zhang, 2015). Study regarding internet addiction measurement tools should be conducted to give more holistic view on internet addiction among students.

\section{CONCLUSION}

It can be concluded from this present study that self-regulated learning relates with internet addiction among university students. Students with high SRL are able to control their internet use and have low tendency in internet addiction. Regarding academic performance, there is no significant correlation between academic achievement and internet addiction. Limitation of this study discussed about the number of participants and the actual behaviour of internet access of the students. Measurement using self report has limited in identifying real internet use of the participants. As a consequence, the result of this study can not be generalized to all first-year students population. Regarding the issue of adjustment among first-year students, future researches should consider other measurement tools to identify more spesific internet access behavior and internet addiction among first-year students.

\section{REFERENCES}

Alt, D. (2015). College students' academic motivation, media engagement and fear of missing out. Computers in Human Behavior, 49, 111 - 119. doi : 10.1016/j.chb.2015.02.057

Barry, S., Murphy, K., \& Drew, S. (2015). From deconstructive misalignment to constructive alignment : Exploring student uses of mobile technologies in university classrooms.Computers \& Education, 81, 202-210. http://dx.doi.org/10.1016/j.compedu.2014.10.014

Calderwood, C., Ackerman, P.L., \& Conklin, E.M. (2014). What else do college students "do" while studying? : an investigation of multitasking. Computers \& Education. $75, \quad 19-29$ http://dx.doi.org/10.1016/j.compedu.2014.02.004

Cazan, A.M. (2013). Teaching Self-regulated learning Strategies for Psychology Students. Procedia Social and Behavioral Sciences, 78, 743-747.

Cho, K. \& Cho, M.H. (2013). Training of Self-regulated learning Skills on a Social Network System. Social Psychology of Education, 16, 617-634.

DSM-5. (2013). Diagnostic and Statistical Manual of Mental Disorders fifth edition. Arlington : American Psychiatric Association.

Dorrenbacher. L., \& Perels, F. (2016). Self-regulated learning profiles in college students: Their relationship to achievement, personality, and the effectiveness of an intervention to foster self-regulated learning. Learning and Individual Differences, 51, 229-241

Dunbar, D., Proeve, M., \& Roberts, R. (2017). Problematic internet usage self-regulation dilemmas: Effects of presentation format on perceived value of behavior. Computers in Human Behavior, 70, 453-459. http://dx.doi.org/10.1016/j.chb.2017.01.015

Gaudreau, P., Miranda, D. \& Gareau, P. (2014). Canadian university students in wireless classrooms: What do they do on their laptops and does it really matter?. Computers \& Education, 70, 245-255. http://dx.doi.org/10.1016/j.compedu.2013.08.019

Hurk, M.V.D. (2006). The Relation Between Self Regulated Strategies and Individual Study Time, Prepared Participation and Achievement in a Problem-Based Curricullum. Active Learning in Higher Education, 7 (2), $155-166$.

Iacovelli, A., \& Valenti, S. (2009). Internet addiction's effect on likeability and rapport. Computers in Human Behavior, 25, 439-443. doi:10.1016/j.chb.2008.10.006

Iskender, M., \& Akin, A. (2010). Social self-efficacy, academic locus of control, and internet addiction. Computers \& Education, 54, 1101-1106. doi:10.1016/j.compedu.2009.10.014

Joinson, A.N. (2003). Understanding The Psychology of Internet Behaviour: Virtual Worlds, Real Lives. New York : Palgrave Macmillan.

Junco, R. \& Cotten, S.R. (2012). No A 4 U: The relationship between multitasking and academic performance. Computers \& Education. 59, 505-514. doi:10.1016/j.compedu.2011.12.023

Judd, T. (2014). Making sense of multitasking : The role of Facebook. Computers \& Education, 70, 194-202. http://dx.doi.org/10.1016/j.compedu.2013.08.013

Kitsantas, A., Winsler, A. \& Huie, F. (2008). Self Regulation and Ability Predictors of Academic Success 
During College : A Predictive Validity Study. Journal of Advanced Academics, 20 (1), 42 - 68.

Kolikant, Y.B.D. (2010). Digital natives, better learners? Students' beliefs about how the Internet influenced their ability to learn. Computers in Human Behavior, 26, 1384-1391. doi:10.1016/j.chb.2010.04.012

Kadioglu, C., Uzuntiryaki, E., \& Aydin, Y.C. (2011). Development of Self RegulatoryStrategies Scale (SRSS). Education and Science, 36 (160), 11-23.

Kuss, D.J., Rooij, A.J.v., Shorter, G.W., Griffiths, M.D., Mheen, D.vd., (2013). Internet addiction in adolescents : Prevalence ad risk factors. Computers in Human Behavior, 29, 1987-1996. doi:10.1016/j.chb.2013.04.002

Kuss, D.J., Griffiths, M.D., Binder, J.F. (2013). Internet addiction in students: Prevalence and risk factors. Computers in Human Behavior, 29, 959-966. http://dx.doi.org/10.1016/j.chb.2012.12.024

Kononova, A., \& Chiang, Y.H. (2015). Why do we multitask with media? Predictors of media multitasking among Internet users in the United States and Taiwan. Computers in Human Behavior, 50, 31-41. http://dx.doi.org/10.1016/j.chb.2015.03.052

Margaryan, A., Littlejohn, A., \& Vojt, G., (2011). Are digital natives a myth or reality? University students' use of digital technologies. Computers \& Education, 56, 429-440. doi:10.1016/j.compedu.2010.09.004

Niu, G.F., Sun, X.J., Subrahmanyam, K., Kong, F.C., Tian, Y., Zhou, Z.K. (2016). Cue-induced craving for Internet among Internet addicts. Addictive Behaviors, 62 , http://dx.doi.org/10.1016/j.addbeh.2016.06.012

Odaci, H. (2011). Academic self-efficacy and academic procrastination as predictors of problematic Internet use in university students. Computers \& Education, $57,1109-1113$.

Peng, C. (2012). Self-regulated learning Behaviour in College Students of Science and Their Academic Achievement. Physics Procedia, 33, 1446-1450.

Roca, N.M., Williams, A.E., \& Dowd, D.K. (2012). The impact of laptop-free zones on student performance and attitudes in large lectures. Computers \& Education, $\quad 59, \quad 1300-1308$. doi:10.1016/j.compedu.2012.05.002

Santrock, J.W. (2011). Life Span Development $11^{\text {th }}$ edition. New York : McGraw-Hill, Inc

Timmis, S. (2012). Constant companions: Instant messaging conversations as sustainable supportive study structures amongst undergraduate peers. Computers \& Education, $\quad 59, \quad 3-18$. doi:10.1016/j.compedu.2011.09.026

Thompson, P. (2013). The digital natives as learners: Technology use patterns andapproaches to learning. Computers \& Education, 65, 12-33. http://dx.doi.org/10.1016/j.compedu.2012.12.022

Taneja, A., Fiore, V., \& Fischer, B. (2015). Cyber-slacking in the classroom: Potential for digital distraction in the new age. Computers \& Education, 82, 141-151. http://dx.doi.org/10.1016/j.compedu.2014.11.009

Taymur, I., Budak, E., Demirci, H., Akda, H.A., Gungor, B.B., Ozdel, K. (2016). A study of the relationship between internet addiction, psychopathology and dysfunctional beliefs. Computers in Human Behavior, 61, 532-536. http://dx.doi.org/10.1016/j.chb.2016.03.043

Walsh, J.L., Fielder, R.L., Kate B. Carey, K.B., \& Carey, M.P. (2013). Female College Students' Media Use and Academic Outcomes: Results From a Longitudinal Cohort Study. Emerging Adulthood, 1(3), 219-232. doi : 10.1177/2167696813479780

Widyanto, L., \& Griffiths, M. (2007). Internet Addiction : Does it Really Exist?. Psychology and The Internet : Intrapersonal, Interpersonal and Transpersonal Implications 2nd edition. London : Elsevier, Inc.

Wu, J.Y. (2017). The indirect relationship of media multitasking self-efficacyon learning performance within the personal learningenvironment : implications from the mechanism of perceivedattention problems and self-regulation strategies. Computers \& Education, 106, 56-72. http://dx.doi.org/10.1016/j.compedu.2016.10.010

Young, K.S. (1998). Caught in The Net : How to Recognize the Signs of Internet Addiction - and a Winning Strategy for Recovery. New York : John Wiley \& Sons, Inc

Young, K.S., \& Abreau, C.N. (2011). Internet Addiction : A Handbook and Guide to Evaluation and Treatment. New Jersey : John Wiley \& Sons, Inc.

Yao, B., Han, W., Zeng, L., \& Guo, X. (2013). Freshman year mental health symptoms and level of adaptation as predictors of Internet addiction: A retrospective nested case-control study of male Chinese college students. PsychiatryResearch, 210, 541-547. http://dx.doi.org/10.1016/j.psychres.2013.07.023

Young, K. S. (2015). The evolution of Internet addiction. Addictive Behaviors. http://dx.doi.org/10.1016/j.addbeh.2015.05.016

Yao, B., Han, W., Zeng, L., \& Guo, X. (2013). Freshman year mental health symptoms and level of adaptation as predictors of Internet addiction: A retrospective nested case-control study of male Chinese college students. PsychiatryResearch, 210, 541-547. http://dx.doi.org/10.1016/j.psychres.2013.07.023

Zimmerman, B.J., Bonner, S. \& Kovach, R. (1996). Developing Self Regulated Learners - Beyond Achievement to Self-Efficacy. Washington : American Psychological Association.

Zimmerman, B.J. \& Schunk (2011). Handbook of Self Regulated Learners and Performance. New York: Routledge-Taylor \& Francis.

Zhang, W. (2015). Learning variables, in-class laptop multitasking and academic performance: A path analysis. Computers \& Education, 81, 82-88. http://dx.doi.org/10.1016/j.compedu.2014.09.012 